TI 2007-058/3

Tinbergen Institute Discussion Paper

Housing Supply and Land Use Regulation in the Netherlands

Wouter Vermeulen $* * * * *)$

Jan Rouwenda/***)

*) CPB, The Hague;

**) VU University Amsterdam. 


\section{Tinbergen Institute}

The Tinbergen Institute is the institute for economic research of the Erasmus Universiteit Rotterdam, Universiteit van Amsterdam, and Vrije Universiteit Amsterdam.

Tinbergen Institute Amsterdam

Roetersstraat 31

1018 WB Amsterdam

The Netherlands

Tel.: $\quad+31(0) 205513500$

Fax: $\quad+31(0) 205513555$

Tinbergen Institute Rotterdam

Burg. Oudlaan 50

3062 PA Rotterdam

The Netherlands

Tel.: $\quad+31(0) 104088900$

Fax: $\quad+31(0) 104089031$

Most TI discussion papers can be downloaded at http:/ /www.tinbergen.nl. 


\title{
Housing supply and land use regulation in the Netherlands
}

\author{
Wouter Vermeulen *), **) \\ w.vermeulen@cpb.nl \\ and \\ Jan Rouwendal **) \\ jrouwendal@feweb.vu.nl
}

Version July 2007

*): CPB Netherlands Bureau for Economic Policy Analysis P.O. Box 80510, 2508 GM, The Hague

**): Free University Amsterdam, Department of Spatial Economics

De Boelelaan 1105, $1081 \mathrm{HV}$, Amsterdam

We gratefully acknowledge useful comments by Nick Draper, Carel Eijgenraam, Jos van Ommeren, Gerard Pfann, Piet Rietveld and Rafael Saitua Nistal, as well as seminar participants at CPB Netherlands Bureau for Economic Policy Analysis, Free University Amsterdam and Maastricht University, and participants of the Housing Economics workshop at the European Network for Housing Research meeting 2007 in Rotterdam. At CPB, Jelte Haagsma, Henk Kranendonk, Ate Nieuwenhuis, Its Siccama, Willemijn van der Straaten and Paul Westra have been helpful in putting together the various datasets used in this paper, or in providing background information. 


\title{
Housing supply and land use regulation in the Netherlands
}

\begin{abstract}
In spite of a growing recognition of the importance of supply conditions for the level and volatility of house prices, empirical work on housing supply outside the US is scarce. This paper considers various measures of housing supply in the Netherlands, where real house prices have roughly tripled since 1970. Besides the volume of investment in residential structures, and new housing construction in units, we derive time series of structure and location quality in a hedonic analysis. Each of these variables appears to be almost fully inelastic with respect to house prices in at least the short to medium long run. Further analysis of the quality of location index shows that conventional models of competitive land and housing markets cannot account for these findings. However, they may be well explained in terms of the rather extensive body of interventions by the Dutch government.
\end{abstract}

Keywords: housing supply, residential investment, housing markets, land use regulation

Classification-JEL: E22, R31, R52 
Long-run developments in house prices may vary dramatically over countries. The average annual increase in real house prices over the period 1971 - 2002 has varied from essentially zero in Germany, Switzerland and Sweden to almost $4 \%$ in the UK (OECD, 2004a). In view of the prominent role of housing in consumer budgets and investment portfolio's, a thorough understanding of what drives such differences is needed. Variation in typical determinants of housing demand, such as trends in the real disposable household income and the real interest rate, has been modest compared to the observed variation in real house price growth. However, similar shifts in demand may lead to strongly divergent price developments under different supply schedules. These simple statistics therefore naturally lead one to wonder about the role of housing supply conditions in these countries.

Supply conditions also matter for house price volatility and aggregate economic stability. Restrictive land use policies may increase the steepness of the housing supply curve, so that the sensitivity of prices to demand shocks is enhanced. In their analysis of the contribution of housing markets to cyclical resilience, OECD (2004a) highlights the impact of the asset price of housing on consumption decisions. It is implied that restrictive supply conditions affect the responsiveness of consumption to housing demand shocks, such as (expectations about) fluctuations in real interest rates. Obviously, volatility in consumption feeds into many other macroeconomic variables. Such considerations have led the UK Treasury to demand for a thorough evaluation of the functioning of the British system of land use controls, at the time that adoption of the Euro was discussed (Barker, 2004, see also Muellbauer, 2005).

Despite its relevance for housing market and aggregate economic outcomes, the body of empirical work on housing supply seems small and fairly inconclusive (DiPasquale, 1999). Estimates of the price elasticity of supply in the US range from 1 to 4 , with outliers from almost zero to infinity, while this literature generally does not deal explicitly with investments in the existing stock. Research on housing supply outside the US is scarce. This is unfortunate, because one would expect to find large international differences in supply elasticities. Institutions in land and housing markets vary substantially between countries, and recent studies point to a strong relationship between the restrictiveness of land use regulation and the price elasticity of housing supply (cf. Green et al., 2005, Quigley and Raphael, 2005). ${ }^{1}$

\footnotetext{
${ }^{1}$ This pattern is confirmed in a few comparative studies (Mayo and Sheppard, 1996, Malpezzi and MacLennan, 2001).
} 
In turn, as we have argued earlier, an enhanced understanding of housing supply conditions may shed light on the large international heterogeneity in trends and volatility of real house prices.

Against this background, the analysis of housing supply in the Netherlands in our paper seems well motivated. Since the early 1970s, real house prices have roughly tripled in this country, and volatility is well above the OECD average (OECD, 2004a). National and local governments intervene in various ways in land and housing markets. Perhaps most fundamentally, the zoning system implies a segmentation of land markets, which essentially turns the supply of residential land into a policy outcome. It is widely known that substantial rents are associated with the transformation of agricultural land to land with a permission for residential use (cf. Dekkers et al., 2004, Segeren, 2007). This implies that restrictions on residential land use are binding, and that they are significant. It is an open issue, however, to what extent such interventions in land and housing markets affect prices at the aggregate level, and the responsiveness of supply. Hence, an analysis of the Dutch case may provide an interesting contribution to the growing body of literature on relationships between land use regulation, housing supply and the level and volatility of prices. ${ }^{2}$

Our empirical work focuses on estimating the price elasticity of housing supply. In order to enhance robustness, we consider a range of supply measures. Annual time series of the volume of investment in residential structures and of new construction in units, for the owner-occupier and the rental sector, are observed from 1970 onwards. Both variables have been studied in the literature, but it should be noted that they measure different aspects of housing supply. Distinguishing tenure seems particularly relevant in our case, as the Dutch rental sector is large and heavily regulated. In addition, we develop several longitudinal indices of housing quality in the owner-occupier sector in a hedonic analysis, using micro data on sales in 1999 and 2000. These allow us to estimate the extent to which housing construction in the preceding decades has responded to price changes through the quality of structures and of locations.

The evidence consistently indicates that housing supply is almost fully inelastic in at least the short to medium long run. The two main potential explanations for a less than fully

\footnotetext{
${ }^{2}$ As a second motivation, we note that the tax deductibility of mortgage interest payments has recently become a topic of fierce debate in the Netherlands, as it is or has been in many other European countries and the US. Welfare effects of this policy depend crucially on the price responsiveness of supply. Van Ewijk et al. (2006) estimate the net social costs of mortgage interest deductibility in the Netherlands to be 0.8 billion Euros $(0.15$ percent of GDP) under a fully elastic housing supply schedule, and to be 2 billion Euros ( 0.4 percent of GDP) under a fully inelastic supply schedule. Hence, our paper constitutes a meaningful contribution to this discussion as well.
} 
elastic long-run housing supply curve are the existence of Ricardian rents in a perfectly competitive setting, and the distorting impact of land use regulations (cf. Glaeser and Gyourko, 2002). Ricardian rents emerge when locations vary in attractiveness, such as in the monocentric model (cf. Fujita, 1989). However, our data are not consistent with one important implication of this framework, which is that the most attractive locations are developed first. Furthermore, the variation in average location quality of new construction over the past decades has by no means been sufficiently large to allow for an explanation of the observed real house price appreciation in terms of Ricardian rents. Hence, it seems more plausible that government interventions in land and housing markets have caused the absence of any significant supply response to prices. A thorough discussion of institutions in these markets suggests that the development of land use policies over time does provide a reasonable explanation for the behaviour of housing supply.

The remainder of this paper starts with a review of the relevant literature. In Section 3, we provide an overview of government interventions in land and housing markets over the past decades. The analyses of residential investment and new construction are presented in Section 4. We proceed by an analysis of adjustments through housing quality, while offering some conclusions in the final section.

\section{A review of the literature}

As housing is a durable good, the market on which it is traded is generally modelled in a stock adjustment framework. Although many variants may be found in the literature, a baseline version of such a model would constitute of two equations. First, the demand for housing must equal supply in the present stock. This determines prices in the short run. Second, the housing stock evolves through construction and depreciation, presumably in response to these prices.

Typically, in these models, the stock does not jump to its long-run level at once, but adjustment takes time. This assumption may be justified on several grounds. In the macroeconomic literature on investment, such lagged adjustment processes are generally understood as a consequence of adjustment costs (cf. Chirinko, 1993). For instance, Topel and Rosen (1988) relate their model of housing investment to this literature, while considering 
both internal and external adjustment costs. ${ }^{3}$ They show that, as a consequence of such costs, it is optimal for the construction industry to smooth output over time. ${ }^{4}$ A more mechanical reason for lags in the construction response to price developments is the time it takes to build a house. This explanation is reinforced when housing supply and land use are strongly regulated, as negotiations with local governments or planning boards may cause additional delays (Mayer and Somerville, 2000b). Finally, the durability of housing implies a downward rigidity in adjustment of the stock.

Building on this economic framework, structural analyses of housing supply consider either residential investment or new construction in units. For instance, Poterba (1984) estimates a model for real investment in structures in the US, reporting a supply elasticity in the range from 0.5 to 2.3. Blackley (1999) analyses the real value of US private residential construction put in place, and reports elasticities ranging from 0.8 to 3.7 , depending on the dynamic specification of her model. These two studies obtain the volume of housing produced by deflating residential investment by a consumer price index, while ignoring the role of land. Topel and Rosen (1988) analyse the price elasticity of new single family housing starts (new one-unit structures on which construction was started during the reference period), reporting a short-run elasticity of 1.0 that is significantly lower than their long-run elasticity of 3.0. ${ }^{5}$

One important aspect ignored in these earlier studies of housing supply is its relationship with land use. Let us consider for instance a Ricardian setting, in which the most preferable housing locations are turned into residential land first. At the margin, residential land rents should equal the rent associated with alternative land use. It follows that in equilibrium, the relationship between the total supply of residential land and rents on inframarginal land is upward sloping. The same result is obtained in standard urban economic theory (cf. Fujita, 1989). As land is an essential input in housing construction, the long-run supply curve of housing is upward sloping as well, even if the construction industry is perfectly competitive. Accounting explicitly for the functioning of land markets, DiPasquale and Wheaton (1994) propose a model for single family housing starts, which includes the

\footnotetext{
${ }^{3}$ External adjustment costs arise from economy-wide upward sloping factor supply curves. Adjustment costs that are internal to the construction industry may be associated for instance with the costs of hiring and firing workers (cf. Mussa, 1977).

${ }^{4}$ Mayer and Somerville (2000b) note that the coefficient of variation of starts is greater than that of sales, which sits uncomfortably with the notion that the construction industry smoothes out investment over time. They suggest that in the US, delays in bringing land from agricultural to urban land use and obtaining building permits may lead investors to smoothen the supply of permitted, developed sites ready for starts.

${ }^{5}$ Both Poterba (1984) and Topel and Rosen (1988) estimate the price elasticity of housing investment, and not the price elasticity of the housing or residential capital stock. These elasticities may differ in general, but DiPasquale and Wheaton (1994) show in a stock-adjustment framework that they are equal in equilibrium.
} 
lagged housing stock. Consistent with the presence of an upward sloping supply curve, they confirm that this variable relates negatively to new construction. The authors report a long-run price elasticity of the stock of 1.2 to 1.4 . Unlike most other studies, their results suggest that it takes several decades for housing supply to converge towards its equilibrium value through new construction.

Mayer and Somerville (2000a) formally derive their housing supply equation from the urban growth model developed by Capozza and Helsley (1989). They also pay more attention than most earlier work to the time series properties of their variables, observing that while construction is a stationary variable, house prices are integrated of order one. The authors therefore specify a model that relates new construction to changes in house prices and construction costs. Quarterly starts of single family dwellings appear to be elastic in the short run, but they find a 0.08 long-run elasticity of the housing stock. Like Topel and Rosen (1988), the authors find that the larger part of the supply response takes place within a year.

Next to the structural analyses we discussed so far, a significant part of the literature on housing supply has relied on reduced form approaches. For instance, a recent paper by Harter-Dreiman (2004) infers the elasticity of housing supply from the long-run relationship between income and house prices at the MSA level. ${ }^{6}$ Underlying her analysis is a simple model of the housing market, in which plausible values are imputed for the demand parameters. ${ }^{7}$ Harter-Dreiman estimates a long-run elasticity of real house prices with respect to real income of 0.27 , from which she infers a lower bound of 1.8 and an upper bound of 3.2 for the price elasticity of supply. Unlike structural models for residential investment or new construction in units, this supply elasticity reflects both land and housing capital, while including investments in the existing stock.

Various authors have suggested that current prices are not a sufficient statistic for housing market conditions. According to Topel and Rosen (1988), the existence of adjustment costs implies that builders take expectations of future house price developments into account. Case and Shiller (1989) relate inefficiency of the housing market to its illiquid character, due to for instance high transaction costs. DiPasquale and Wheaton (1994) argue that slow clearing of the housing market is related to search frictions, as housing is highly heterogeneous and search is time consuming. The consequence of such distortions is that a

\footnotetext{
${ }^{6}$ We refer to DiPasquale (1999) for a discussion of earlier work on housing supply that adopts a reduced-form framework.

${ }^{7}$ It is shown in this framework that the price elasticity of supply must equal the price elasticity of demand plus the ratio of the income elasticity of demand and the income elasticity of the price in the long run. The author
} 
price elasticity of supply may underestimate the responsiveness of new construction to market conditions. This may explain why most structural analyses of housing supply find large effects of variables like time on the market, vacancy rates and interest and inflation rates, although their effect should be small or absent in perfectly competitive markets.

Another common feature of studies on US housing supply is the poor performance of cost variables. For instance, none of the measures for construction costs in Poterba (1984), Topel and Rosen (1988) and DiPasquale and Wheaton (1994) have a significant impact on starts. Blackley (1999) reports a positive sign for wages in the construction industry in a specification in levels, but she finds a modest negative effect of wages in a specification in first differences. DiPasquale (1999) suggests that these anomalies in the literature may be due to measurement problems, as most studies use aggregate data rather than data where the builder is the unit of observation. A second reason may be the insufficiency of the price statistic. For example, a variable like the interest rate may contain additional information on housing market conditions. As in business cycle peaks, both output in the construction industry and the interest rate tend to be relatively high, the estimated coefficient for this latter variable may be biased if the state of the business cycle is not appropriately accounted for. ${ }^{8}$

Facilitated by the emergence of regional panel data, more recent work on housing supply in the US pays attention to the role of land use regulation. For instance, Mayer and Somerville (2000b) estimate effects of delays, the use of growth management techniques and development fees on the number of single family permits in a panel of US metropolitan areas. They report that the elasticity of permit supply may be up to 20 percent lower in regulated cities, predominantly as a result of delays in obtaining approval for subdivisions (zoning) of land. Harter-Dreiman (2004) finds a long-run supply elasticity in the range between 1.0 and 2.1 for cities with tight spatial planning, while a range between 2.6 and 4.3 is estimated for unconstrained cities. Using the same urban economic model as Mayer and Somerville (2000a), Green et al. (2005) estimate MSA specific elasticities of the supply of building permits, which appear to vary wildly between cities. They find a negative relationship between these elasticities and a regulatory index. Quigley and Raphael (2005) perform a similar analysis for cities in California, and they report a significantly negative relationship between the supply elasticity of the housing stock and their regulatory index as well.

assumes that the price elasticity of demand ranges between -1.0 and -0.5 , and that the income elasticity of demand ranges between 0.75 and 1.0 .

${ }^{8}$ Another issue may be nonstationarity. Notably, Mayer and Somerville (2000) cannot reject the presence of a unit root in real house prices, the real prime rate and the real material price index in levels, but most other studies 
Furthermore, the authors argue that the house price boom in this region is largely attributable to regulatory stringency.

Much less work on housing supply has been done outside the US. A particularly extensive investigation into housing supply conditions has been performed under the authority of the UK Treasury (Barker, 2003, 2004). It reports a supply elasticity of almost zero, which is attributed at least partly to restrictive land use planning. Furthermore, a few international comparative studies exist, that also suggest a significant effect of land use policies. Malpezzi and Maclennan (2001) infer the price elasticity of housing supply in the US and the UK from a long-run relationship between income and house prices in these countries. For the post war period, they report a range between 0 and 0.5 for the UK, while estimated elasticities are much higher for the US. ${ }^{9}$ Using essentially the same method, Mayo and Sheppard (1996) estimate supply elasticities for Thailand, Korea and Malaysia. In both studies, the relationship between regulatory stringency in a country and the elasticity of supply is negative. Moreover, Mayo and Sheppard identify the negative impact of a British style land use regulation system in Malaysia on a shift in the supply elasticity after its introduction in the seventies. Finally, OECD (2004a) reports supply elasticities for a limited number of countries, reporting a strongly negative correlation of this variable with house price volatility over the period 1971 2002.

The few recent papers that exist on housing investment in the Netherlands diverge substantially in their estimates of the supply elasticity. A study by Hakfoort and Matysiak (1997) largely follows Topel and Rosen (1988). Given the extent of government intervention in the social rental sector, which is relatively large in the Netherlands, the authors only consider unsubsidized housing starts between 1977 and 1994. Like Topel and Rosen, they prefer the specification that takes account of adjustment costs. They find a short-run price elasticity of 2.3 and a long-run elasticity of 6 , which would suggest that housing supply is more elastic in the Netherlands than it is in the US. ${ }^{10}$ At the other extreme, Swank et al. (2002) study the supply of building permits, and they cannot reject a price elasticity of zero, while their point estimate is 0.3 . In a recent study of the fiscal treatment of housing in the

on US housing supply make use of these variables, without reporting tests for stationarity. Regressions that include nonstationary variables are prone to spurious relationships.

${ }^{9}$ Similarly, Meen (2002) finds that the elasticity of supply explains most key differences between housing markets in the US and the UK.

${ }^{10}$ Although their paper is not concerned with the price elasticity of housing supply, lags in the construction industry are also analysed in Merkies and Steyn (1994). The authors allow for time-varying lag structures, using quarterly data. They find lags of at most three years, which is roughly consistent with findings in Topel and Rosen (1988). We remark that these lags do not necessarily reflect delays in the supply of residential land that result from regulations. 
Netherlands, Koning et al. (2006) obtain the elasticity of the total supply of housing services from calibration of a structural model that is essentially based on Poterba (1984). The authors infer a long-run price elasticity of 0.65 . Finally, some indirect evidence may be found in analyses of Dutch house prices, which generally find high long-run elasticities of income. For instance, OECD (2004b) reports a long-run elasticity of real house prices with respect to real disposable income per household of 0.84 , and Verbruggen et al. (2005) estimate this elasticity to be well over unity. The long-run price elasticity of total housing supply implied by an income elasticity of unity, using the same model and demand parameters as in HarterDreiman (2004), would range between -0.25 and 0.5 .

\section{$3 \quad$ Institutional setting}

As discussed in the previous section, analyses of housing supply are generally founded on the macroeconomic investment literature or on urban economic theory. However, it is not a priori clear to what extent either macroeconomic or urban models of housing investment are applicable to a housing market that is highly regulated. For instance, the free market assumptions underlying both types of models are violated if the supply of residential land is a policy outcome. In that case, the price elasticity of housing supply essentially reflects the extent to which this policy is sensitive to price signals. Moreover, in such a setting, the relationship between housing supply and other variables, such as construction and opportunity costs, is also weakened. Therefore, in this section, we provide a brief overview of government interventions in housing and land markets in the Netherlands, which may contribute significantly to an understanding of housing supply patterns over the past decades.

While certain forms of land use regulation have existed for centuries in the Netherlands, relating for instance to protection against floods, the foundations of modern spatial planning were laid in the Housing Act (Woningwet) of 1901. In this industrial era, the main focus was on the improvement of living conditions for the poor. The Housing Act obliged municipal governments to develop and enforce formal zoning plans, which would facilitate the provision of elementary facilities such as water and sewerage. At the same time, housing corporations were established for the construction of social rental housing, predominantly in the largest cities of the Netherlands.

Government involvement in housing supply was boosted in the aftermath of the Second World War. Severe damage of the production capacity led to government planning of investments in industries and infrastructure. In view of a major housing shortage, and in order 
to keep wage pressure down, the government set rents substantially below the free market level. The construction of social rental housing was subsidized, and annual production quantities were planned as well. ${ }^{11}$ In subsequent years, this range of policies evolved into a more encompassing planning strategy, elaborated in a series of White Books (Nota's van de Ruimtelijke Ordening).

The legal framework for land use regulation during our period of observation is the Spatial Planning Act (Wet op de Ruimtelijke Ordening) of 1965. This act constitutes a topdown process, in which the national government provides rough guidelines, which are translated to a lower scale at the provincial level, and finalized by municipalities. Together, the eventual municipal zoning plans designate a detailed function (housing, industry, offices, shops, recreation, ...) to each lot of land. ${ }^{12}$ These plans have to be updated about every ten years, in a process that may take several years. Furthermore, they are legally binding, and the procedure to make amendments is rather lengthy. Hence, in this system, the supply of residential land is indeed a government affair, and market signals can have effects only to the extent that government institutions are sensitive to them. Moreover, even if these institutions are responsive to price signals, then legal procedures significantly delay such responses.

In subsequent decades, the national spatial planning strategy has balanced two conflicting purposes. On the one hand, a strong political support for involvement in housing supply has remained in place long after World War II. Besides various other policy interventions, this was manifest in spatial planning through provision of the land necessary to realize residential production targets. On the other hand, it has always put a strong emphasis on the preservation of landscape heritage and open space. For example, from the sixties onwards, residential development between the four main cities of Amsterdam, Rotterdam, The Hague and Utrecht has been heavily restricted, while preserving the so-called 'Green Heart' area. For similar reasons, a 'growth centre policy' in the seventies and eighties of the previous century aimed to accommodate population growth in especially designated, and sometimes newly created towns, while restricting expansion of the larger cities nearby. Furthermore, there appears to have been a continued focus on compact development. Nowadays, it is a policy aim that $40 \%$ of new construction is infill development. Hence, it seems fair to conclude that land use regulation has always been restrictive, at least at certain

\footnotetext{
${ }^{11}$ In addition, other institutions existed that hampered unsubsidized construction by private firms.

${ }^{12}$ Formally, not every piece of land is subject to a zoning plan, but changes in land use, in particular if the function is going to be residential use, have to be legally approved everywhere in the country.
} 
locations, while showing a tendency to direct people towards other locations, deemed more desirable from a social point of view. ${ }^{13}$

In the course of the 1980s, the political agenda changed, and the sense of urgency with respect to housing construction waned. This resulted in a major change in Dutch housing policy in the beginning of the 1990s, when most of the subsidies on housing construction were abandoned, and housing corporations were liberalised. The responsibility for the realization of housing supply and the provision of associated local public goods, such as parks, roads and social housing, was shifted towards local governments and market parties (commercial developers and housing corporations). As expected, this policy change lead to a substantial decrease in the construction of social rental housing. The rental sector, which accounted for about two thirds of the housing stock in 1970, is presently dominated quantitatively by the owner-occupier sector. However, construction in the owner-occupier sector in the 1990s was not significantly higher than it was in the second half of the seventies either. On the contrary, Dutch housing construction reached a post war trough in 2003, although the high level of house prices was unprecedented even in real terms. ${ }^{14}$

Various explanations for the low rates of construction in the past one and a half decade have been raised. For instance, Priemus (1998) has argued that the government's weakening interest in housing construction has been replaced by an increasing interest in environmental issues like the preservation of landscape heritage and open space. The ministry of housing, spatial planning and the environment (VROM), while continuing to formulate ambitious goals with respect to housing production, became responsible only for the realization of the environmental goals. Hence, it may have complicated residential construction by market parties through the restrictive supply of land. However, this cannot be the full explanation, as Jókövi et al. (2006) document that even for many locations that were designated for new housing construction, the targets were not reached, or reached only with substantial delay. Another culprit may have been the way in which planning procedures deal with the price of land. It has become conventional to compute the value of land as the residual that results when costs of construction are subtracted from the potential sales revenues. This residual is used to finance the acquisition and conversion of land, and the provision of local public

\footnotetext{
${ }^{13}$ After World War II, spatial policies also aimed to keep the population density in peripheral regions at a level that was sufficiently high to sustain the supply of local public services. This ended during the economic crisis in the early 1980s. Empirical evidence of the directive character of Dutch land use regulation may be found in a simultaneous regional analysis of housing supply, migration and employment growth by Vermeulen and Van Ommeren (2006).

${ }^{14}$ During our period of observation, construction in the owner-occupier sector was only lower during the crisis of the early 1980s.
} 
goods. ${ }^{15}$ Furthermore, the associated costs are borne predominantly by developers in the private sector, so that social housing construction is still subsidized. This system thus levies an (implicit) development tax on residential land for private construction, which is conditioned on potential sales revenues. In negotiations with market parties, municipalities have probably varied their demands for local public good provision with the expectations of these revenues. Hence, market signals to the construction sector about the optimal size and composition of the housing stock may have been dampened, or even fully undermined (cf. Conijn, 2006). ${ }^{16}$

While our account of Dutch government interventions in land and housing markets in this section is far from exhaustive, it may provide sufficient reason to believe that institutional arrangements have led to an emphasis on planning and negotiation, while severely limiting the potential to react to market forces. ${ }^{17}$ Fundamental in this institutional setting, we believe, is the regulation of land use. Throughout the past decades, the supply of residential land at attractive locations has been either limited directly, or it has been implicitly taxed by municipalities, or permissions were granted conditional on rather specific requirements on the type of housing to be built. Residential land is an essential component of housing production, and possibilities for the substitution of capital for land are further limited by prohibitions on high-rise buildings in most places. We see no reasons to believe that the Dutch construction industry is particularly uncompetitive in the long run. In this setting, it makes sense to interpret the price elasticity of housing supply predominantly as a measure for the price responsiveness of the body of institutions that supply residential land.

We note that policy makers may be less sensitive to demand revealed through prices than market parties. For instance, the Dutch government projects housing demand on the basis stated preferences, such as expressed in the Dutch housing demand survey (WBO), and demographic models. This approach yields an estimate of the "housing need", which,

\footnotetext{
${ }^{15}$ This approach is often motivated by Ricardian analysis of land rent, where policymakers interpret this theory as claiming that the value of housing determines the value of land (cf. Evans, 1999). However, it should be observed that Ricardian analysis refers to market outcomes, and not to planning procedures. Clearly, in a segmented land market, restrictions on the supply of residential land will push up house prices.

${ }^{16}$ In the planning process, the level of house prices is taken as given when plans are developed. Since many parties with different interests are involved, many claims on the surplus exist. Market power by land owners, which is reinforced by legal privileges, may have made negotiations particularly cumbersome and time consuming. If market conditions deteriorate, as they did in the beginning of the 2000s, plans can only be changed after renegotiations that may again take years. It should also be noted that the need for mutual agreement and planning is forced upon all parties involved by the limited availability of sites for residential location, which strongly reduces opportunities to react elsewhere to market incentives in a more appropriate way. Development of new sites is usually a sequential process and the next location will only come available when negotiations over the ones that are presently planned have been completed.

${ }^{17}$ For instance, we have not discussed requirements on housing structures, and their impact on new construction.
} 
confronted with the number of housing units in the existing stock, leads to a certain "housing shortage" ${ }^{18}$ Resolving this shortage has often been an explicit policy goal, particularly in the decades after the Second World War. To the extent that the supply of residential land relies on demographic projections, shifts in demand that result from for instance rising incomes and falling interest rates are ignored. Hence, it is by no means obvious that the government fully internalizes demand when making land use decisions, even in the long run.

\section{$4 \quad$ Analysis of residential investment and new construction}

The literature review in Section 2 suggests that amongst the reasons for the ongoing controversy on the price elasticity of housing supply are the problems associated with measurement. Housing supply arises through various channels, such as new construction or conversions in the existing stock. Furthermore, housing quality and location are potentially important aspects. However, housing quality is ignored in studies that focus on units, permits or housing starts, and the spatial aspect is ignored in most studies that have relied on national data. In order to obtain a robust set of estimates of the price elasticity of housing supply in the Netherlands, we perform a range of analyses on various datasets. The quality of housing structures and location, and their relationship to prices, will be the subject of the next section. In this section, we consider the volume of residential investment and new construction in units, both for the total housing market and for the owner-occupier sector.

\subsection{Data}

We consider annual data over the period 1970 - 2005. Observations for this full period are available for all variables except for the volume of residential investment and the residential capital stock, for which consistent time series are available until 2003.

Residential investment consists of both the value of new housing structures and the value of investments in the existing stock, while ignoring the value of investments in residential land. This variable is estimated in a national accounting framework by Statistics Netherlands (CBS), using information on output in the construction industry. Hence, in

\footnotetext{
${ }^{18}$ The difference between these policy notions and demand functions in economic theory is that the former do not account for the relationship between demand and prices. Hence, policy may ignore that the "housing need" is lower at the current high level of prices than it would have been at the marginal costs of producing a house. Another complicating issue is the heterogeneity of housing. It would seem preferable from a theoretical point of view to discuss the demand and supply of housing services, rather than units.
} 
practice, only the larger investments in the stock, such as renovation projects and major house improvements, are measured. In this paper, we are interested in the extent to which the volume of residential investment responds to prices. It is obtained by deflating the value of residential investment by a construction cost index, although we note that this price-volume split may not be fully reliable. ${ }^{19}$ We also consider the residential capital stock, which has been estimated by CBS in a vintage model (cf. Van den Bergen et al., 2005). The construction of this variable requires additional assumptions on depreciation of the housing capital stock, which are also quite difficult to verify. Hence, some caution in interpreting the analyses that use these data is warranted. Finally, it should be noted that these variables do not allow for the distinction between an owner-occupier and a rental sector.

Our second measure of housing supply is the number of newly constructed housing units. These data, as well as information on the total stock of housing, are provided by CBS. A new housing unit consists of a structure component and a residential land component. Furthermore, this measure clearly reflects the volume of investments, so separating out price effects is not an issue here. However, both the quality component (or residential capital intensity) and investments in the existing stock are fully ignored. The data on new construction allow for a distinction between the rental and the owner-occupier sector. This seems relevant, as government involvement is less strong in this latter sector, so we might find a different response to prices. The share of owner-occupied housing in the total housing stock is measured every four years in a housing demand survey (WBO). For other years, we have estimated this share using information on construction of rental and owner-occupied housing, and on conversions.

A central variable in our analysis is the price of housing. Ideally we would have used a constant quality (hedonic or repeat sales) price index, as in most studies of US housing supply. However, such an index is unavailable for the Netherlands over the period we consider here, and we have to rely on an index referring to median sales price of Dutch houses. This series is put together from an index provided by the Dutch Association of Realtors (NVM) from 1970 to 1978, and an index provided by the land register (Kadaster) from 1978 onwards. For a much shorter period of observation, starting in 1993, the land register has constructed a repeat sales index. Somewhat surprisingly, this index shows a substantially faster increase than median sales prices over the period until $2006 .{ }^{20}$ Hence it

\footnotetext{
${ }^{19}$ Even if the volume of residential investment is fully price inelastic, then its value still correlates to prices, so an imperfect price-volume split may lead to an overestimation of this elasticity.

${ }^{20}$ Possibly, this index does not properly account for investments in existing houses between two sales.
} 
does not suggest that we overestimate the quality adjusted price increase by using median sales prices.

In the housing supply equations, we use a number of controls that are similar to variables used in the US literature. Construction costs are measured as the real residential investment deflator, such as used in the national accounts. ${ }^{21}$ Furthermore, we include the real long interest rate as a measure for opportunity costs of foregone investment in other markets. Both variables should affect housing supply negatively. As an instrument for prices, which are at least theoretically endogenous, we use the real disposable labour income per full-time equivalent (FTE).

In the previous section, we have argued that Dutch institutions may be responsive to other variables than prices. In particular, the government has traditionally used the concept of "housing need", which is estimated with stated preference data and demographic models. We proxy this variable with an estimate of the total number of households, that is obtained using age specific headship rates in a base year (1985) and the evolution of the age composition of the population (cf. DiPasquale and Wheaton, 1994). Including this variable in our analysis, we may investigate the hypothesis that as a consequence of restrictive planning, demographic projections of demand explain supply better than the demand revealed in prices.

\section{Please insert Table 1 somewhere around here.}

Descriptive statistics for all variables are provided in Table 1. Following Mayer and Somerville (2000a), we pay particular attention to the time series properties of our data. Hence, for each variable, we show descriptives for both levels and changes, and report an Augmented Dickey-Fuller test statistic (augmented with one lag and a linear trend) for the presence of a unit root. Mayer and Somerville find that most of their variables are nonstationary in levels, but stationary in changes, where new construction is interpreted as the change in the housing stock. Similarly, the unit root tests in Table 1 indicate that most of our variables in levels have a unit root. Since our time series are relatively short (unlike Mayer and Somerville, we do not use quarterly data), and since the Dickey-Fuller test is not very powerful, it seems reasonable to adopt a low level of significance for rejection of a unit root. If we take a significance level of $20 \%$, a unit root is rejected for all variables in changes,

\footnotetext{
${ }^{21}$ We have obtained this series from the OECD, which uses the same measure for construction costs in OECD (2004b). Statistics Netherlands also has a time series of residential construction costs based on building permits. The two series are almost fully congruent.
} 
except for the demographic variable. For some variables, such as total new construction and price changes, a unit root is rejected at a much higher level of significance. Hence, we will treat the detrended first-differenced variables as stationary in our subsequent analyses. The behaviour of the demographic variable will be discussed more extensively in the next subsections.

Using nonstationary variables in a regression analysis may have severe consequences. In particular, there is an increased risk of multi-colinearity, which may lead to spurious relationships. This may be an issue for the majority of US studies on housing supply that ignore the presence of unit roots in explanatory variables. In our analysis, we avoid these problems by adopting a two-step approach. In the next subsection, we consider the variables in levels, while investigating the presence of co-integrating relationships. In particular, we consider the existence of a long-run relationship between housing supply and prices, such as predicted in a Ricardian model of the land market, and the existence of a long-run relationship between housing supply and our demographic variable, such as may be expected in the Dutch institutional context. In subsection 4.3, we will study short-run relationships in an analysis of variables in changes.

\subsection{Analysis of stock variables}

Figure 1 presents our three measures of the stock of housing supply, the volume of the residential capital stock, the total housing stock and the stock of owner-occupied housing, as well as the level of prices and demographic demand. For the purpose of comparability, all variables in this figure are indices, where their value for 1970 is set to 100 . Over the period considered, the volume of residential capital has increased by more than $150 \%$, whereas the housing stock increased by approximately $85 \%$. This suggests a substantial increase in the volume of residential capital per housing unit, which may have occurred both through increasing quality of new units, and through investments in the existing stock. Furthermore, we note that the stock of owner-occupied housing has roughly tripled over our period of observation, whereas the rental housing stock increased by only about $30 \%$, so that the share of the owner-occupier sector in the total housing stock has risen from less than a third to about $55 \%$.

Please insert Figure 1 somewhere around here. 
The same figure also shows the development of the level of real house prices. This variable shows a much greater volatility over time than the three housing stock measures, which have increased steadily over time. The boom in the second half of the seventies stands out in particular. It has been attributed to high inflation rates, translating into low or even negative user costs of housing. ${ }^{22}$ The bubble busted after a major increase in the real interest rate, and real house prices halved within a few years. The boom in the second half of the nineties is generally associated with rising incomes and falling interest rates (cf. Verbruggen et al., 2005), and a significant price correction has not yet been observed. ${ }^{23}$ The figure does not suggest that these booms have significantly marked the development of housing supply in either of the three measures.

\section{Please insert Table 2 somewhere around here.}

As the variables shown in Figure 1 are nonstationary, any relationships inferred from inspection of this figure run a high risk of being spurious. We consider the existence of cointegrating relationships between prices and our three measures for the level of supply, by testing for the presence of a unit root in the residuals of bivariate regressions of these relationships. Table 2 shows regressions of the house price index on our supply variables, as well as Augmented Dickey-Fuller test statistics (augmented with one lag and a linear trend) on the residuals. In order to facilitate interpretation, we report the implied elasticity at the sample average, rather than regression coefficients. The table indicates that the level of house prices correlates strongly with both the volume of the residential capital stock, the total number of housing units and the size of the owner-occupier housing stock. All three variables increase by about half a percent, if the level of house prices increases with one percent. Furthermore, this relationship appears to explain about half of the variance in these supply variables. However, in the residuals of these regressions, a unit root cannot be rejected at any conventional level of significance. Hence, no co-integrating relationships appear to be present, and the reported correlations are likely to be spurious.

\section{Please insert Figure 2 somewhere around here.}

\footnotetext{
${ }^{22}$ Furthermore, credit constraints were eased in the early 1970s, and a law was passed that made it possible to split houses into separate apartments. This pushed up the demand from lower-income households in particular.
} 
In our interpretation of these findings, we focus on the relationship between prices and the total housing stock. These two variables are plotted against each other in Figure 2. In a perfectly competitive setting, in which the special features of land markets would be irrelevant, house prices should be determined by construction costs in the long run. As construction costs have developed roughly in the same way as the consumer price index, real house prices should be stationary and the curve in Figure 2 should be flat. However, both the test for a unit root in the real house price index reported in Table 1 and inspection of this figure are inconsistent with these predictions. Hence, the competitive model with fully elastic supply of land seems strongly at odds with our findings.

Nonstationarity of prices may be reconciled with a perfectly competitive setting once the existence of a long-run upward sloping supply curve of land is recognized, as in a Ricardian framework or, more specifically, in urban economic theory. In this setting, prices and the total housing stock should be co-integrated, and Figure 2 should trace out the long-run supply curve of housing. However, our analysis in Table 2 rejects the existence of such a cointegrating relationship. As a consequence, the curve in Figure 2 cannot be interpreted as a long-run supply schedule, and the regressions in Table 2 do not identify the long-run price elasticity of supply. It is implied that our findings are also at odds with a perfectly competitive Ricardian model, a claim that will be verified more extensively in the next section. ${ }^{24}$

While the findings in this section cannot be reconciled with conventional models of competitive land and housing markets, they may alternatively be understood within the Dutch institutional context, in which the supply of residential land is essentially a policy outcome. We have argued in Section 3 that policy makers may not be that sensitive to demand signals as revealed in prices, relying rather on stated preference information and demographic models. In this setting, the price elasticity of supply is likely to be reduced, and supply responses may be delayed. However, our findings are not consistent with a positive response of housing supply to prices within the medium long run of less than a decade either. In that case, as in the Ricardian framework, prices and the total housing stock should be cointegrated, and Figure 2 should trace out the long-run supply curve of housing. Hence, the

\footnotetext{
${ }^{23}$ In the early 1990s, credit constraints were again relaxed. In particular, it became possible to obtain a mortgage on the household income, rather than the income of the household head.

${ }^{24}$ This analysis assumes a linear long-run relationship between supply and prices. One might argue that our failure to find a co-integrating relationship is due to a nonlinear shape of this relationship. Hence, we have investigated the existence of a co-integrating relationship between supply and a second degree polynomial of real house prices, but the presence of a unit root in the residual of a regression of supply on prices and their square could not be rejected either.
} 
institutional framework appears to have resulted in a fully inelastic housing supply schedule, at least in the medium long run.

We argue that lags in the adjustment process of more than a decade are implausible on both theoretical and empirical grounds. Clearly, adjustment costs in the construction industry, such as analysed by Topel and Rosen (1988), cannot account for lags of such length (see also Merkies and Steyn, 1994, for the Netherlands). However, there is no obvious reason for policy makers either to respond to price signals of more than a decade earlier, rather than to current price signals or even to expectations of future demand. Since spatial planning in the Netherlands has been predominantly a top-down process, it seems reasonable to assume that major adjustments in national policies that restrict the supply of residential land become effective after the publication of White Books on the national planning strategy. This would imply that revisions have taken place more frequently than once in the ten years. ${ }^{25}$ Hence, if adjustments to market signals would indeed occur at these moments, we should have identified a positive supply elasticity in the medium long run. Yet, this is not what we found in the data. Notably, after publication of the 1997 White Book on spatial planning, no adjustment of supply to the rise in house prices star ting in the early 1990s was observed. On the contrary, new construction has decreased in the subsequent years (see also Figure 4 and the analysis in the next subsection). Finally, if institutions would respond elastically to price signals, but with substantial delay, we would still expect to find a positive short-run relationship between new construction and price changes. However, as indicated in the next section, such a relationship appears to be absent as well.

The findings in Table 2 do appear to be consistent with an alternative interpretation, which is that housing supply is not responsive to prices at all, but that it follows some autonomous process. One possible process would be that Dutch institutions respond to the "housing need", estimated on the basis of stated preference information and demographic models. We briefly explore this option in an analysis of our demographic demand variable. Figure 1 contains the development of this variable over time. By the nature of demographic processes, the age composition of the population changes only slowly over time. Hence, by construction, our demand variable moves gradually over time as well. The figure suggests a particularly strong correlation with the evolvement of the total stock. This is precisely the pattern one would expect to find in a setting in which total housing supply in units were

\footnotetext{
${ }^{25}$ National White Books on spatial planning have appeared in 1973 (Derde Nota: Oriënteringsnota), 1976 (Derde Nota: Verstedelijkings-nota), 1985 (Derde Nota: Structuurschets Stedelijke Gebieden), 1988 (Vierde Nota), 1992 (Vierde Nota Extra), 1997 (Vierde Nota Actualisatie) and 2004 (Nota Ruimte).
} 
predominantly the outcome of a political process, focussed on the accommodation of "housing needs".

\section{Please insert Table 3 somewhere around here.}

We analyse bivariate relationships between demographic demand and our three measures of housing supply more formally in Table 3 . The regressions shown in this table suggest strong correlations between these variables, as variation in the supply variables appears to be explained almost to full extent. A one percent increase in the estimated number of households based on the age composition of the population is associated with a two percent increase in the volume of the residential capital stock, a more than one percent increase in the total housing stock and a more than two percent increase in the owner-occupier housing stock. These estimates are not too far from the unit-elasticity that might be expected. ${ }^{26}$ However, again, in the residuals of these regressions, a unit root cannot be rejected at any conventional level of significance. So there is no evidence of co-integrating relationships of supply variables with demographic demand either. One might argue that our approximation of the "housing need" is crude, and that estimates that would take account of exogenous changes in headship rates and preferences, to the extent that governments take account of them, would have done a better job, but we leave this issue for future work.

\subsection{Models for investment and new construction}

As no co-integrating relationships amongst the nonstationary variables were found, we proceed with an analysis of variables in changes, similar to Mayer and Somerville (2000a). Instead of changes in the measures for the stock of supply, we consider investments and new construction. Deprecation or demolitions are ignored, as these processes are expected to respond to prices to a much smaller extent. Figure 2 shows the volume of residential investment and changes in the house price index, while new construction for the total housing market and for the owner-occupier sector are shown in Figure 3.

Please insert Figures 3 and 4 somewhere around here.

\footnotetext{
${ }^{26}$ As headship rates have increased over time, it is not surprising that the estimates are above one. However, it is somewhat peculiar to find that housing supply in the owner-occupier sector responds more strongly to our
} 
Figure 3 suggests a positive relationship between investment and price changes, in particular in the second half of our period of observation. However, such a relationship does not appear to be present for new construction. Figure 4 indicates that the level of construction of owner-occupied housing is more or less constant over the period 1970-2005, with the exception of the early 1980s and the most recent years. The fall in construction in the early eighties in this sector is likely to be a response to the collapse in house prices. However, falling construction rates towards the end of our period of observation have occurred after a major increase in house prices. The downward trend in total housing construction reflects falling construction rates in the rental sector, which have apparently not been compensated by increased production for the owner-occupier sector. Furthermore, Figure 4 does not suggest that the relationship between prices and construction has altered over our period of observation. The contrast with supply conditions in the US becomes particularly clear when we compare this figure to Figure 2 in Mayer and Somerville (2000a), which shows new housing starts and price changes in the US.

The responsiveness of residential investment and new construction to price changes is estimated more formally in a regression analysis. This analysis controls for changes in real construction costs and changes in the real long interest rate, which proxies the opportunity costs of investment in the residential market. In the model for construction in the owneroccupier sector, we include construction in the rental sector in order to control for crowding out effects. Furthermore, we include changes in the demographically estimated demand, as a measure for the aims that policy makers may pursue. In the specification presented, we have not included any lags of the explanatory variables. Most US studies do include lags, but many analyse quarterly rather than annual data. Nevertheless, we allow for lagged adjustment processes by including a lag of the dependent variable in our specification. ${ }^{27} \mathrm{~A}$ linear trend is removed from the variables, which makes all of them stationary (see Table 1), except changes in demographic demand. Hence, the coefficient of this variable should be interpreted with particular caution.

\footnotetext{
demographic variable than the total housing stock, although this is the less regulated sector. Such anomalies could of course turn up if these relationships are indeed spurious.

27 Given the institutional context, there will always be a delay between price changes and responses in construction. However, to some extent, price changes are likely to be anticipated, so that it still makes sense to use current price changes. We have experimented with lags of price changes as well, but this did not affect our overall findings. Furthermore, we have tested for autocorrelation in the residuals of our regressions, using a second order Breusch-Godfrey test (Table 4 reports the associated p-values). The null hypothesis of no autocorrelation could not be rejected at the $5 \%$ level of significance in any of the three models. This suggests that these models do not suffer from omission of important dynamic effects.
} 
The identification of supply elasticities is generally obscured by a simultaneous response of prices to supply. In housing markets, though, this issue is relatively unimportant because of their stock nature. New construction usually adds only a small fraction to the existing stock, in our data this was about $2 \%$ on average for the total housing stock. This means that in the short run, house prices are determined through the interaction of demand and supply in the existing stock, and not through new construction. Exogeneity of housing supply is even more plausible in the Dutch institutional setting, in which price responses are strongly delayed or even disabled through the zoning system (see Section 3). We have tested for endogeneity of prices changes by instrumenting them with changes in the real disposable labour income per FTE. Studies of house prices generally find that these are strongly affected by income. However, there is no particular reason to believe that housing supply would be responsive to income changes, rather than to price changes, so that the validity of this instrument seems plausible. As reported in Table 4, a Wu-Hausman test cannot reject the null hypothesis of exogeneity of price changes at any conventional level of significance for residential investment and total new construction, while it is rejected at the $10 \%$ level for construction in the owner-occupier sector. We report the result of estimation with OLS for all three measures in Table 4, whereas IV results for construction in the owner-occupier sector are discussed separately in the text.

\section{Please insert Table 4 somewhere around here.}

We find that investment and construction in the owner-occupier sector respond positively to price changes, while the estimated coefficient for total construction is negative. Only the response of investment is statistically significant at the $5 \%$ level. However, quantitatively, it so low as to be almost negligible. As exogeneity of real house price changes is rejected at the $10 \%$ level of significance for the owner-occupier sector, we have estimated the same model with IV, using changes in the real disposable labour income per FTE as an instrument. This yields an estimated elasticity at the sample average of 0.037 , with a standard deviation of 0.019 , so the OLS results appear to underestimate the price elasticity of new construction in this sector. If we use the IV coefficient instead, the long-run effect of a $1 \%$ increase in prices is an increase in new construction of less than $0.1 \%$, and an increase in the owner-occupier housing stock of less than $0.002 \%$. These results may be contrasted with the reported elasticities in Mayer and Somerville (2000a), who find that a $1 \%$ price increase leads to a $3.7 \%$ increase in starts in the same year, and to a $0.08 \%$ adjustment in the stock in 
the long run. Moreover, the small supply response in the Dutch owner-occupier sector is apparently offset by construction in the rental sector. ${ }^{28}$

We now turn to the estimated coefficients of the other variables. Both for the volume of residential investment and for new construction, the effect of construction costs is positive, while it is statistically significant at the $5 \%$ level for investment and construction in the owner-occupier sector. Therefore, as in many other studies on housing supply, we find a perverse effect for this variable (cf. DiPasquale, 1999). Possibly, this control variable picks up a business cycle effect that is not accounted for by the other variables. Consistent with its interpretation as a proxy for opportunity costs, the coefficient for the real long interest rate is negative, although its effect appears to be small and statistically insignificant. Finally, we find a small negative effect of construction in the rental sector on construction on the owneroccupier sector, which is not statistically significant either. ${ }^{29}$

Consistent with the view that through the zoning system, housing supply is essentially a policy outcome, and that policymakers are more responsive to demographic "housing needs" projections than to prices, we find relatively large effects of changes in demographic demand on investment and construction in the owner-occupier stock. Moreover, the imprecision of the coefficient estimate for total construction allows for an elasticity of similar magnitude. However, nonstationarity of this variable makes this finding rather uncertain, while the estimated standard errors should be considered with particular suspicion. Furthermore, it is not reassuring that the effect appears to be the weakest for total construction, while we would expect it to be stronger than for the other supply measures. Hence, we judge the time series evidence in support for the demographic variable to be mixed at best.

In our discussion of the institutional setting in Section 3, we have mentioned various changes in policies that occurred around 1990. One may wonder whether these institutional

\footnotetext{
${ }^{28}$ The supply of owner-occupied housing units may also occur through conversions. In order to account for this, we have estimated a model for changes in the owner-occupied housing stock, which was otherwise similar to the specifications in Table 4. A price elasticity of 0.046 with a standard deviation of 0.035 was found with OLS estimation, whereas instrumenting house price growth with income growth lead to an elasticity of 0.17 , with a standard deviation of 0.12 . This suggests that conversions from rental to owner-occupied housing have been responsive to house price developments, although the economic significance of these effects remains limited.

${ }^{29}$ As construction in the rental sector is a policy outcome (for a substantial part of the stock, rents are set below market levels), it makes sense to treat this variable as exogenous. Instrumenting it with its first lag yielded similar results. In this respect, it should also be noted that the price considered throughout this paper is the median sales price of owner-occupied housing. In a perfectly competitive equilibrium, this price would correspond to the present discounted value of all future rents for a similar house in the rental sector. However, as most rents are regulated, this present value is lower than prices in the owner-occupier sector for most houses. Taking account of these institutions, actors in the rental sector would probably show a higher responsiveness to
} 
shifts have marked the relationship between price changes and new housing supply. In order to test for this, we have estimated the same model, extended with an interaction effect of price changes and a dummy that took the value 1 after 1990. The p-value of a test for statistical significance of this interaction effect is reported in Table 4. The absence of a shift in the effect of price changes on the volume of residential investment and total construction could not be rejected at any conventional level of significance. However, for construction in the owneroccupier sector, the absence of a shift is rejected at the $20 \%$ level of significance. Interestingly, the coefficient of the interaction effect implies that the elasticity of construction in this sector with respect to price changes was positive before 1990, and negative after. Hence, there is some indication that the institutional changes have reduced the price responsiveness of construction in the private sector, which appears to be in line with the discussion of these changes by Priemus (1998). ${ }^{30}$

\section{$5 \quad$ Adjustments in the quality of housing structures and locations}

The limited price sensitivity of investment in residential structures suggests that besides the price sensitivity of new construction in units, the price sensitivity of the quality of new construction and of investments in the existing housing stock are limited as well. ${ }^{31}$ Nevertheless, given the difficulty of measuring the volume of residential investment, we perform a corroborative analysis in this section, using a different approach. We estimate the valuation of various aspects of housing quality, which are observed in a large dataset of housing transactions over the period 1999 - 2000. By averaging the value of these characteristics for each year of construction between 1970 and 2000, we obtain indices for several aspects of quality. These indices are related to the median house price index series of the previous section, in order to obtain an estimate of their price responsiveness. Necessarily, this approach is restricted to the owner-occupier sector.

More formally, we estimate the following regression:

prices. For instance, Figure 4 points to a fall in construction of rental housing around 1990, when direct subsidies on construction were abolished.

${ }^{30}$ Furthermore, the positive supply elasticity before 1990 may be driven by the fall in new construction during the housing market crises in the early 1980s. It seems plausible that restrictive institutions hamper downward adjustments less than upward adjustments, such as required in the 1990s.

31 Note that this finding may be reconciled with a competitive construction industry, if real house price developments are predominantly driven by changes in land prices, which seems plausible in the Dutch institutional context. 
$\log \left(P_{r, \tau}\right)=C+D_{t=2000}+\sum_{i} \alpha_{i} M_{i}+\sum_{j} \beta_{j} X_{j}+\gamma_{r} I_{r}+\delta_{\tau} I_{\tau}+\varepsilon_{r, \tau}$

in which the dependent variable is the logarithm of $P_{r, \tau}$, the price of a house in region $r$ that is constructed in year $\tau$. Next to a constant $C$ and $D_{t=2000}$, a control for whether the house has been sold in 2000, the regression contains maintenance controls $M_{i}$, measures for structure quality $X_{j}$, a dummy $I_{r}$ for the municipality in which the house is situated and a dummy $I_{\tau}$ for the year of construction. The structure quality of new construction in year $t$ is measured by the average of the structure component $Q_{t}^{X}=E\left(\sum_{j} \beta_{j} X_{j} \mid \tau=t\right)$, where $E(\mid \tau=t)$ denotes an expected value conditional on the year of construction. We construct a structure quality index as $I_{t}^{X}=100 *\left(1+Q_{t}^{X}-Q_{1970}^{X}\right)$, so that the index has a value of 100 in 1970 . An index value of 110 in year $t$ indicates that housing built in year $t$ is worth $10 \%$ more on average in 1999 2000 than housing built in 1970 due to the increased average quality of structures. The indices $I_{t}^{L}$ for location and $I_{t}^{M}$ for maintenance quality are constructed similarly, using the components $Q_{t}^{L}=E\left(\sum_{r} \gamma_{r} I_{r} \mid \tau=t\right)$ and $Q_{t}^{M}=E\left(\sum_{i} \alpha_{i} M_{i} \mid \tau=t\right)$ respectively. Finally, an index that picks up effects of the year of construction on the house value in 1999 - 2000 that are not accounted for by the other indices is constructed as $I_{t}^{T}=100 *\left(1+\delta_{t}-\delta_{1970}\right)$. When estimating Equation (1), we choose 1970 as a reference year, so that $\delta_{1970}=0$.

Equation (1) is estimated on a large sample of housing transactions in the years 1999 and 2000, obtained from the association of Dutch real estate brokers (NVM). The real estate brokers that are member of this association cover the majority of housing market transactions in the Netherlands. Throughout our analysis, we will assume that this dataset is representative for the entire Dutch housing stock. Amongst the variables reported for each transaction are the transaction price and date, the year of construction, two maintenance controls (interior and exterior of the dwelling), a range of quality characteristics and the location of the dwelling. The quality controls consist of size variables and proxies for the type of housing, such as detached, semi-detached, terraced housing or bungalow. We measure the quality of housing location at the level of municipalities. This level of aggregation captures the majority of the spatial variation in house prices. Only single family dwellings are considered in order to enhance homogeneity of our sample. After dropping implausible outliers and houses built before 1970, this leaves a sample of about 80,000 observations. Because of the noisiness of 
the data, we estimate Equation 1 by a least absolute distance (LAD) estimator. ${ }^{32}$ Figure 5 shows the quality indices, which are constructed using sample characteristics and these coefficient estimates.

\section{Please insert Figure 5 somewhere around here.}

Figure 5 suggests that the quality of new structures has responded strongly to the housing crisis in the beginning of the 1980s. Houses built in the years 1982 - 1983 are worth now almost $20 \%$ less than houses built in 1970, because they are on average either smaller or of a less attractive type (terraced housing rather than free-standing), while these structure attributes seem to yield a similar value to houses built in the 1990s as in 1970. In contrast, the developments of the maintenance index and in particular of the residual time component index suggest that from the early 1980s onwards, housing quality has increased with the year of construction. Houses built in 2000 are about 15\% more expensive than houses built in 1970 due to other components than observed structure quality, maintenance and location. Obviously, the quality of new housing is determined by many factors, of which we observe only a fraction in our dataset. Finally, the quality of location has remained rather stable over the 1970s, while increasing significantly in the 1980s. In the early 1990s it dropped, and it increased again towards the end of our period of observation.

The relationships between house prices and each of the four quality indices presented in Figure 4 are analysed more formally in a regression analysis. ${ }^{33}$ We transform all variables into logarithms, so that the estimated coefficients can be interpreted directly as elasticities. Similar to our analysis in Section 4.3, we estimate bivariate relationships for each variable in changes, while removing all linear trends. We do not account for the potential endogeneity of

\footnotetext{
${ }^{32}$ Because of the large number of municipalities, we have computed median house prices at the municipal level in a first step, and then estimated the valuation of housing characteristics on house prices relative to this median in a second step. This procedure is analogous to demeaning in a municipal fixed effects model. The estimated coefficients for this regression are available upon request, and they generally match with findings in the hedonic pricing literature.

${ }^{33}$ A number of caveats should be borne in mind when adopting this approach. In the first place, the quality of housing is not fixed after its construction. People may alter the quality characteristics of their house through maintenance activities or other investments. Obviously, this holds in particular for the maintenance index. Hence, the quality indices that are estimated on characteristics and prices in 1999 - 2000 do not necessarily reflect the quality at the moment of construction of the dwelling. So if, for instance, owners of a house built in the period 1982 - 1983 have invested more than average in their dwelling, then we have underestimated the price responsiveness of the index of structure quality. A second issue is that over the past decades, the demand for quality attributes may have changed as well. So quality adjustments that were deemed highly valuable in the 1970s may not be reflected fully in transaction prices in the period $1999-2000$.
} 
price changes, which may be justified by the assumption that price changes are predominantly determined in the existing stock. ${ }^{34}$ The results are shown in Table 5.

\section{Please insert Table 5 somewhere around here.}

The relationship between the house price index and the index of structure quality is statistically significant. The estimated coefficient implies that a $1 \%$ increase in house prices leads to about a $0.14 \%$ increase in the index of structure quality, which means that houses built in the period in which this price increase would have occurred, would have a $0.14 \%$ higher value due to increased structure quality. Although quality adjustments may materialize through other characteristics than the ones we observe, the economic and statistical insignificance of the price sensitivity of the index of the residual time component of quality suggests that our index of structure quality captures the most important quality adjustments. The price elasticity of the maintenance index is statistically significant but negligible in size. In the previous section, we have found that a $1 \%$ price increase lead to a less than $0.1 \%$ increase in new construction in the owner-occupier sector. This suggests that price adjustments of new housing supply in this sector are slightly stronger in the quality dimension than in the number of units. Obviously, these elasticities refer to adjustments in new construction, whereas adjustments of the total stock are much smaller.

We do not find any economically or statistically significant relationship between prices and the index of location quality. In an unregulated land market, one would expect that higher prices would lead to more development on attractive and expensive locations. Hence, this finding seems strongly at odds with the assumption of perfect competition on land markets. In the previous section, we have discussed the possibility that prices have risen over the past decades as a result of an upward sloping supply curve of residential land. In perfectly competitive markets again, this would be consistent with the Ricardian model that was explained in Section 2. An implication of this setting is, that the quality of location of new housing is decreasing with the size of the total housing stock. It is this decrease in quality that causes average house prices to rise through Ricardian rents. Figure 6 shows a scatter plot of the quality of location index and the indexed total housing stock. This plot does not point to a

\footnotetext{
${ }^{34}$ Table 5 reports test statistics for the exogeneity assumption, where the growth rate of the real disposable labour income per FTE is used as an instrument. Exogeneity of real house price growth is rejected only for the location index. In all regressions in which real house price growth is instrumented with income growth, the estimated coefficient of the price growth variable is lower than for the OLS regressions, so if anything, we appear to overestimate the price elasticities.
} 
negative relationship between these variables. Furthermore, it shows that the quality index has hardly varied, whereas the total housing stock almost doubled. Hence, it seems implausible that Ricardian rents have lead to an upward sloping supply curve of housing that is sufficiently steep, to account for the observed increase in prices.

\section{Please insert Figure 6 somewhere around here.}

Again, developments in Dutch housing market institutions may provide a more accurate description of shifts in the quality of location than competitive models of land and housing markets. In the 1970s, spatial planning focused strongly on "clustered deconcentration" of new housing construction. In this era, many "new towns" were founded or assigned, in which the growth of housing demand in nearby large cities was to be accommodated. However, the quality of location index suggests that these locations are not perceived as the most attractive ones by housing consumers. ${ }^{35}$ Houses built in the aftermath of the housing market crises are worth about $5 \%$ more on average than houses built in the 1970s, due to a higher quality of location. The steep shift suggests that the government has responded to the demand induced trough in new construction, not only by increasing production in the regulated rental sector, but also by making available more attractive locations. Also, efforts to stimulate a more even distribution of the population over the country were strongly reduced, as the need for people to locate near jobs was acknowledged during this severe economic crisis. Furthermore, the focus of the national planning strategy shifted towards (compact) development the larger cities in the 1980s. The fall of the quality of location index in the early 1990s and its subsequent rise appear to be somewhat more difficult to explain. They may be related to institutional reforms in the housing market, which have arguably lead to an increased focus on environmental quality (Priemus, 1999). During the 1990s, locations at the fringe of the large cities (so called VINEX locations) were assigned for the accommodation of new housing demand. Production in these locations started to pick up somewhat towards the end of the 1990s. Housing production in these locations may have caused the final rise of the construction quality index in our data.

\footnotetext{
${ }^{35}$ This is confirmed by spatial house price differentials. For example, housing in Almere, one of the largest of the "new towns", is worth about $30 \%$ less than housing in nearby Amsterdam, once differences in the quality of structures are controlled for.
} 
Housing supply in the Netherlands is almost fully inelastic in the short-run. Our estimates suggest that new construction in the owner-occupier rises with $0.04 \%$ after a $1 \%$ price increase in the same year, while for total construction, no significant response could be identified at all. In a comparable econometric analysis, Mayer and Somerville (2000a) report a one-year response for the US that is higher by about a factor 100. Furthermore, we find that the long-run effect of a $1 \%$ price increase on new construction in the owner-occupier sector is a $0.1 \%$ increase, which yields a $0.002 \%$ increase of the housing stock in this sector. These elasticities may arguably be considered as negligible for any practical purposes.

Housing supply may respond to price changes not only through the number of newly constructed dwellings, but also through their quality, and through investments in the existing stock. We have analysed the volume of investment in residential structures, which measures the amount of capital invested in both new and existing dwellings. This variable was found to be even less elastic with respect to house prices in the short run than new construction in the owner-occupier sector. Furthermore, we have estimated a time series of the structure quality of new owner-occupied housing in a hedonic analysis. This index appears to be responsive to house prices in the short run with an elasticity of about 0.1 . These results indicate that shortrun supply responses through other channels than new construction in units were economically insignificant as well.

Whereas both prices and the stock housing, measured either in units or in the volume of residential capital, are nonstationary, we could not identify a co-integrating relationship between them. This finding would be consistent with a positive long-run supply elasticity only if lags in the adjustment process are in the order of a decade, or even longer. Hence, we may conclude that housing supply is inelastic in at least the medium long run. Furthermore, it does not seem plausible that lags of such length can be attributed to rigidities in the construction industry, such as analysed in Topel and Rosen (1988). However, it is also difficult to reconcile them with Dutch institutions in land and housing markets, as there is no reason to believe that politicians or civil servants would respond to price developments of more than a decade earlier, rather than addressing present (or expected future) needs. Moreover, if these institutions would be responsive to prices, but with significant lags, we would still expect to find a larger short-run elasticity. Therefore, it seems reasonable to interpret our findings as evidence of a fully inelastic long-run housing supply schedule. 
A less than perfectly elastic housing supply curve may be reconciled with undistorted housing and land markets in a Ricardian model, in which locations vary in desirability. If housing market developments in the Netherlands were to be explained within this competitive framework, then locations that are presently available for new construction should be inferior to available locations in the early 1970 s to the extent that average house prices have tripled to make inframarginal housing equally attractive as new construction. The quality of location index that we have estimated in our hedonic analysis is not consistent with this framework at all. In the first place, this index shows that the quality of location has varied with only a few percent over the past decades, so that it cannot account for the long-run trend in house prices quantitatively. Secondly, the average quality of location of new construction has not decreased with the size of the total housing stock, so it is not the case that the most desirable locations have been developed first. From this, we conclude that our findings regarding housing supply and prices in the Netherlands cannot be reconciled with conventional models of competitive land and housing markets.

Our paper has provided an overview of various government interventions in land and housing markets over the past decades. Pivotal in these interventions appears to be the regulation of land use, so that the supply of residential land is legally a government decision, rather than a market outcome. Consequently, the supply elasticities estimated in this paper should be interpreted predominantly as a measure for the responsiveness of these institutions to price signals. Over the past decades, governments have planned construction following estimates of the housing need, which may have relied more on demographic models and stated preferences than on the demand revealed in prices. The protection of open space and the direction of residential development towards certain locations deemed socially desirable has been another consistent policy aim. Furthermore, since the early 1990s, new residential land has been implicitly taxed in order to finance local public goods. It seems plausible that these policies, as well as, doubtlessly, many other aspects of intervention in land and housing markets, have together been the cause of an aggregate housing supply schedule that is almost fully inelastic.

Housing demand has increased substantially over the past decades as a consequence of rising incomes, falling interest rates and demographic developments. Rising demand leads to rising prices if supply does not respond. This seems an accurate explanation for the long-run trend in real house prices in the Netherlands, which has been remarkably high from an international perspective (OECD, 2004a). Having established that Dutch housing supply is almost fully inelastic as a consequence of land use regulation, we must conclude that 
government interventions in land and housing markets have contributed significantly to the present high level of house prices in this country.

\section{References}

Blackley, D. M. (1999). “The long-run elasticity of new housing supply in the US: empirical evidence for 1950 to 1994." Journal of Real Estate Finance and Economics, 18(1), 25 $-42$.

Barker, K. (2003). Review of housing supply: interim report - analysis. HM Treasury, London.

Barker, K. (2004). Review of housing supply: final report - recommendations. HM Treasury, London.

Capozza, D. R. and Helsley, R. W. (1989). "The fundamentals of land prices and urban growth.” Journal of Urban Economics, 26(3), 295 - 306.

Case, K. E. and Shiller, R. J. (1989). "The efficiency of the market for single-family homes." American Economic Review, 79(1), 345 - 363.

Chirinko, R. S. (1993). "Business fixed investment spending: modeling strategies, empirical results, and policy implications.” Journal of Economic Literature, 31(4), 1875 - 1911.

Conijn, J. (2006). "De koopsector: een verstorende factor op de woningmarkt." Economisch Statistische Berichten, 91(4499), 630 - 633.

Dekkers, J., Rietveld, P., Van den Brink, A. and Scholten, H. (2004). "Exploring the land market in the province of Noord-Holland using a spatial regression model." Paper for the $44^{\text {th }}$ congress of the European Regional Science Association.

DiPasquale, D. (1999). "Why don't we know more about housing supply?" Journal of Real Estate Finance and Economics, 18(1), 9 - 23.

DiPasquale, D. and Wheaton, W. C. (1994). "Housing market dynamics and the future of housing prices." Journal of Urban Economics, 35(1), 1 - 27.

Evans, A. W. (1999). "The land market and government intervention.” In Cheshire, P. C. and Mills, E. S. (eds), Handbook of Regional and Urban Economics, Volume 3, North Holland, Amsterdam.

Fujita, M. (1989). Urban economic theory. Cambridge University Press, Cambridge, UK.

Glaeser, E. L. and Gyourko, J. (2002). "The impact of zoning on housing affordability." NBER Working Paper No. 8835. 
Green, R. K., Malpezzi, S. and Mayo, S. K. (2005). "Metropolitan-specific estimates of the price elasticity of supply of housing, and their sources." American Economic Review, 95(2), $334-339$.

Hakfoort, J. and Matysiak, G. (1997). "Housing investment in the Netherlands." Economic Modelling, 14(4), 501 - 516.

Harter-Dreiman, M. (2004). "Drawing inferences about housing supply elasticity from house price responses to income shocks.” Journal of Urban Economics, 55(2), 316 - 337.

Jókövi, J., Boon, C. and Filius, F. (2006). Woningproductie ten tijde van VINEX. Rotterdam/Den Haag: NAi Uitgevers/RPB.

Koning, M. A., Saitua Nistal, R. and Ebregt, J. (2006). Woningmarkteffecten van aanpassing fiscale behandeling eigen woning. CPB Document 128, Den Haag.

Malpezzi, S. and Maclennan, D. (2001). "The long-run price elasticity of supply of new residential construction in the United States and the United Kingdom." Journal of Housing Economics, 10(3), 278 - 306.

Mayer, C. J. and Somerville, C. T. (2000a). "Residential construction: Using the urban growth model to estimate housing supply." Journal of Urban Economics, 48(1), 85 - 109.

Mayer, C. J. and Somerville, C. T. (2000b). "Land use regulation and new construction." Regional Science and Urban Economics, 30(6), 639 - 662.

Mayo, S. and Sheppard, S. (1996). "Housing supply under rapid economic growth and varying regulatory stringency: An international comparison.” Journal of Housing Economics, 5(3), 274 - 289.

Meen, G. (2002). “The time series behavior of house prices: a Transatlantic divide?” Journal of Housing Economics, 11(1), 1 - 23.

Merkies, A. H. Q. M. and Steyn, I. J. (1994). "Modelling changing lag patterns in Dutch construction.” Journal of Economic Dynamics and Control, 18(2), 499 - 509.

Muellbauer, J. (2005). "Property taxation and the economy after the Barker Review." Economic Journal, 115(502), C99 - C117.

Mussa, M. (1977). "External and internal adjustment costs and the theory of aggregate and firm investment." Economica, 44(174), 163 - 178.

OECD (2004a). "The contribution of housing markets to cyclical resilience." OECD Economic Studies, 38(1), 125 - 156.

OECD (2004b). OECD Economic Surveys Netherlands. OECD Paris.

Poterba, J. M. (1984). "Tax subsidies to owner occupied housing: an asset market approach." Quarterly Journal of Economics, 99(4), 729 - 752. 
Priemus, H. (1998). "Contradictions between Dutch housing policy and spatial planning." Tijdschrift voor Economische en Sociale Geografie, 89(1), 31 - 43.

Quigley, J. M. and Raphael, S. (2005). "Regulation and the high cost of housing in California." American Economic Review, 95(2), 323 - 328.

Segeren, A. (2007). De grondmarkt voor woningbouwlocaties. Belangen en strategieën van grondeigenaren. Rotterdam/Den Haag: NAi Uitgevers/RPB.

Swank, J., Kakes, J. and Tieman, A. F. (2002). The housing ladder, taxation and borrowing constraints. DNB Report No. 9, Amsterdam.

Topel, R. H. and Rosen, S. (1988). "Housing investment in the United States." Journal of Political Economy, 96(4), 718 - 740.

Van den Bergen, D., De Haan, M., De Heij, R. and Horsten, M. (2005) "Measuring capital in the Netherlands." Paper prepared for the OECD Working Party on National Accounts, Paris, 11-14 October 2005.

Van Ewijk, C. Jacobs, B. and De Mooij, R. (2006). "Doelmatigheidswinst van minder hypotheekrenteaftrek.” Economisch Statistische Berichten, 91(4489), 292 - 295.

Verbruggen, J., Kranendonk, H., Van Leuvensteijn, M. and Toet, M. (2005). Welke factoren bepalen de ontwikkeling van de huizenprijs in Nederland? CPB Document 81, Den Haag.

Vermeulen, W. and Van Ommeren, J. N. (2006). "Housing supply and the interaction regional population and employment." CPB Discussion Paper No. 65. 
Table 1: Descriptive statistics for the longitudinal analyses

\begin{tabular}{|c|c|c|c|c|c|c|c|}
\hline Variable & mean & std. dev. & minimum & maximum & \# obs. & ADF & p-value \\
\hline \multicolumn{8}{|c|}{ volume of residential capital $(1,000,000$ units of a 2001 Euro $)$} \\
\hline stock & 407430 & 105458 & 228069 & 586589 & 34 & -2.93 & 0.15 \\
\hline investment & 17953 & 2463 & 14405 & 22366 & 34 & -2.92 & 0.16 \\
\hline \multicolumn{8}{|c|}{ total housing units $(1,000)$} \\
\hline stock & 5580 & 983 & 3763 & 6955 & 36 & -0.19 & 0.99 \\
\hline new construction & 101 & 24 & 60 & 155 & 36 & -3.92 & 0.01 \\
\hline \multicolumn{8}{|c|}{ housing units owner-occupier sector $(1,000)$} \\
\hline stock & 2574 & 765 & 1270 & 3815 & 36 & -1.95 & 0.63 \\
\hline new construction & 55.2 & 8.5 & 34.1 & 69.1 & 36 & -2.83 & 0.19 \\
\hline \multicolumn{8}{|c|}{ housing units rental sector $(1,000)$} \\
\hline stock & 3006 & 256 & 2494 & 3287 & 36 & -0.79 & 0.97 \\
\hline new construction & 46 & 26 & 13 & 97 & 36 & -4.04 & 0.01 \\
\hline \multicolumn{8}{|c|}{ median house price index } \\
\hline level & 174 & 66 & 100 & 318 & 36 & -2.17 & 0.50 \\
\hline changes & 6.2 & 16.3 & -38.6 & 49.0 & 35 & -3.68 & 0.02 \\
\hline \multicolumn{8}{|c|}{ real construction cost index } \\
\hline level & 124 & 11 & 100 & 150 & 36 & -2.56 & 0.30 \\
\hline changes & 1.42 & 2.46 & -4.61 & 5.43 & 35 & -3.18 & 0.09 \\
\hline \multicolumn{8}{|c|}{ real long interest rate (\%) } \\
\hline level & 3.3 & 2.2 & -1.4 & 7.0 & 35 & -1.41 & 0.86 \\
\hline changes & 0.022 & 1.083 & -2.383 & 1.971 & 34 & -4.52 & 0.00 \\
\hline \multicolumn{8}{|l|}{ demographic demand } \\
\hline level & 5749 & 733 & 4487 & 6818 & 36 & 0.81 & 1.00 \\
\hline changes & 66.6 & 14.3 & 30.2 & 90.1 & 35 & -0.39 & 0.99 \\
\hline \multicolumn{8}{|c|}{ real disposable labour income per FTE (in 1970 Euros) } \\
\hline level & 5887 & 750 & 4438 & 7198 & 36 & -1.93 & 0.64 \\
\hline changes & 76 & 131 & -213 & 263 & 35 & -2.78 & 0.20 \\
\hline
\end{tabular}


Table 2: Long-run relationships between housing supply and prices

\begin{tabular}{l|ccc}
\hline & capital (volume) & total stock (units) & o.o. sector (units) \\
\hline real house price index & 0.554 & 0.319 & 0.612 \\
& $(0.095)^{* * *}$ & $(0.058)^{* * *}$ & $(0.083)^{* * *}$ \\
\hline \# observations & 34 & 36 & 36 \\
$\mathrm{R}^{2}$ & 0.518 & 0.475 & 0.614 \\
ADF statistic & -2.56 & -1.82 & -1.72 \\
p-value & 0.30 & 0.69 & 0.74 \\
\hline
\end{tabular}

Notes: Standard errors appear in parenthesis, * indicates significance at $10 \%$ level, $* *$ indicates significance at 5 $\%$ level and $* * *$ indicates significance at $1 \%$ level. In order to facilitate interpretation of the coefficients, we report the elasticity evaluated at the sample average.

Table 3: Long-run relationships between housing supply and demography

\begin{tabular}{l|ccc}
\hline & capital (volume) & total stock (units) & o.o. sector (units) \\
\hline demographic demand & 2.103 & 1.378 & 2.321 \\
& $(0.026)^{* * *}$ & $(0.019)^{* * *}$ & $(0.038)^{\star * *}$ \\
\hline \# observations & 34 & 36 & 36 \\
$\mathrm{R}^{2}$ & 0.995 & 0.993 & 0.991 \\
ADF statistic & -0.92 & -2.35 & -0.71 \\
p-value & 0.95 & 0.41 & 0.97 \\
\hline
\end{tabular}

Notes: Standard errors appear in parenthesis, * indicates significance at $10 \%$ level, ** indicates significance at 5 $\%$ level and $* * *$ indicates significance at $1 \%$ level. In order to facilitate interpretation of the coefficients, we report the elasticity evaluated at the sample average.

Table 4: Short-run analysis of housing supply

\begin{tabular}{l|ccc}
\hline & investment & tot. construction & o.o. sector \\
\hline$\Delta$ (real house price) & 0.0085 & -0.0038 & 0.011 \\
& $(0.0032)^{* *}$ & $(0.0071)$ & $(0.007)$ \\
$\Delta$ (real construction costs) & 0.014 & 0.0036 & 0.032 \\
& $(0.006)^{* *}$ & $(0.0109)$ & $(0.012)^{* *}$ \\
& -0.00031 & -0.00054 & -0.00040 \\
$\Delta($ real interest rate) & $(0.00017)^{*}$ & $(0.00035)$ & 0.00036 \\
& 0.109 & 0.0028 & 0.280 \\
construction r.s. & $(0.057)^{*}$ & $(0.1081)$ & $(0.113)^{* *}$ \\
& & & -0.012 \\
lagged dependent & 0.577 & $0.074)$ \\
& $(0.110)^{* * *}$ & $(0.148)^{* * *}$ & 0.466 \\
\# observations & 32 & 34 & $0.130)^{* * *}$ \\
$\mathrm{R}^{2}$ & 0.784 & 0.422 & 34 \\
Breusch-Godfrey (p-value) & 0.08 & 0.20 & 0.693 \\
Exogeneity price (p-value) & 0.56 & 0.23 & 0.28 \\
No break in 1990 (p-value) & 0.67 & 0.98 & 0.06 \\
\hline
\end{tabular}

Notes: Standard errors appear in parenthesis, * indicates significance at $10 \%$ level, $* *$ indicates significance at 5 $\%$ level and $* * *$ indicates significance at $1 \%$ level. Linear trends have been removed from all variables. In order to facilitate interpretation of the coefficients, we report elasticities evaluated at the sample average. Furthermore, $\mathrm{p}$-values are reported of a Breusch-Godfrey test for second order autocorrelation, and of a Wu-Hausman test for endogeneity of the change in the real house price index. The test for a break in the effect of house prices after 1990 was implemented by testing for the statistical significance of an interaction effect of the price change variable with a dummy that assumes the value 1 after 1990 in an extended version of the model. 
Table 5: Price elasticity of various quality indices of new housing

\begin{tabular}{l|cccc}
\hline & structure & location & maintenance & residual \\
\hline$\Delta \log ($ real house price) & 0.136 & 0.050 & 0.005 & 0.031 \\
& $(0.058)^{\star *}$ & $(0.039)$ & $(0.002)^{\star *}$ & $(0.015)^{\star}$ \\
\hline \# observations & 30 & 30 & 30 & 30 \\
$\mathrm{R}^{2}$ & 0.16 & 0.06 & 0.16 & 0.12 \\
Breusch-Godfrey (p-value) & 0.72 & 0.55 & 0.47 & 0.98 \\
Exogeneity price (p-value) & 0.62 & 0.02 & 0.52 & 0.96 \\
\hline
\end{tabular}

Notes: Standard errors appear in parenthesis, * indicates significance at $10 \%$ level, ** indicates significance at 5 $\%$ level and $* * *$ indicates significance at $1 \%$ level. We consider first differences of the logarithm of prices and quality indices, where linear trends have been removed from all variables. Furthermore, p-values are reported of a Breusch-Godfrey test for second order autocorrelation, and of a Wu-Hausman test for endogeneity of the change in the real house price index. 
Figure 1: The indexed stock three housing supply measures, real prices and demography

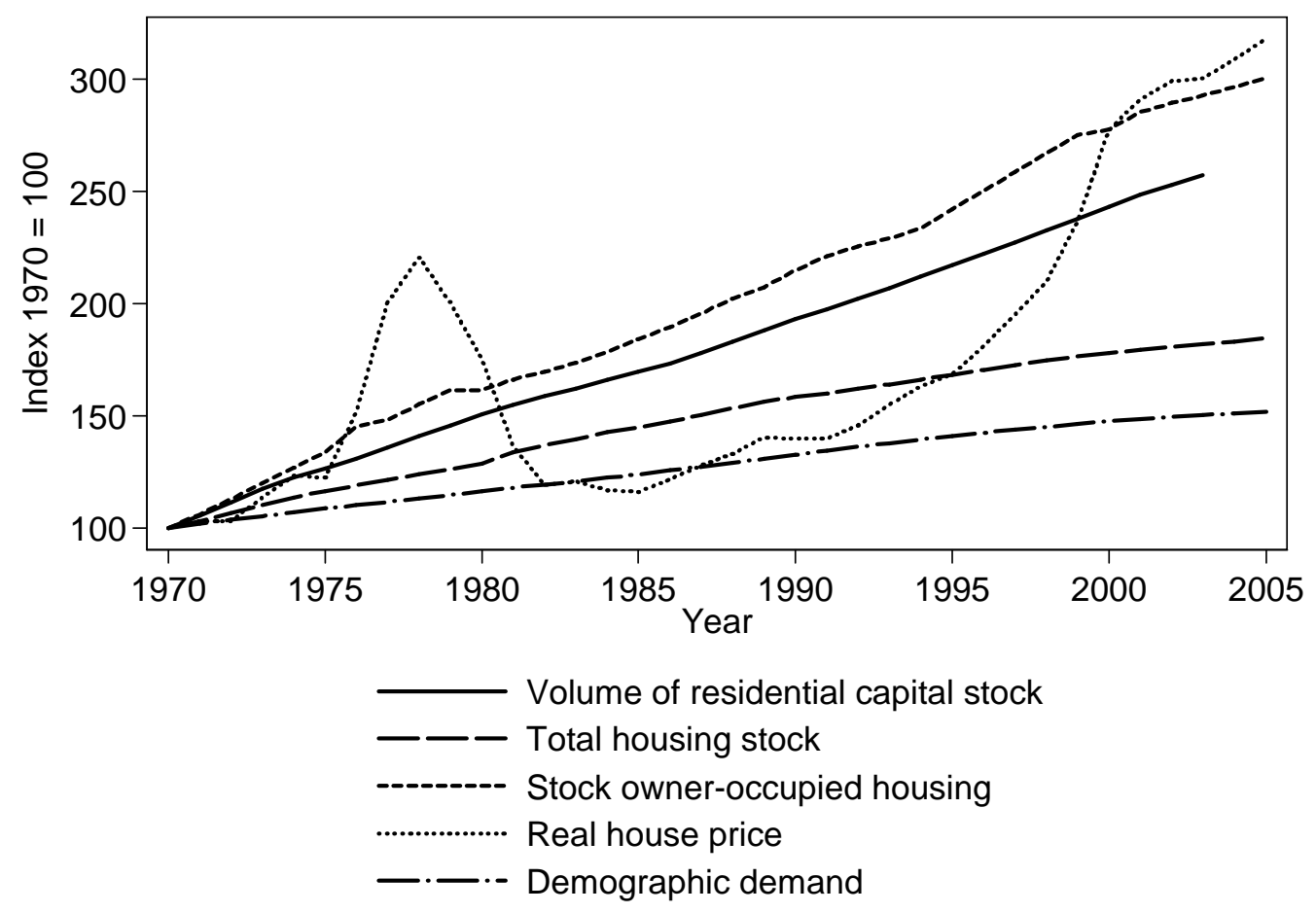

Figure 2: A scatter plot of house prices and the total stock

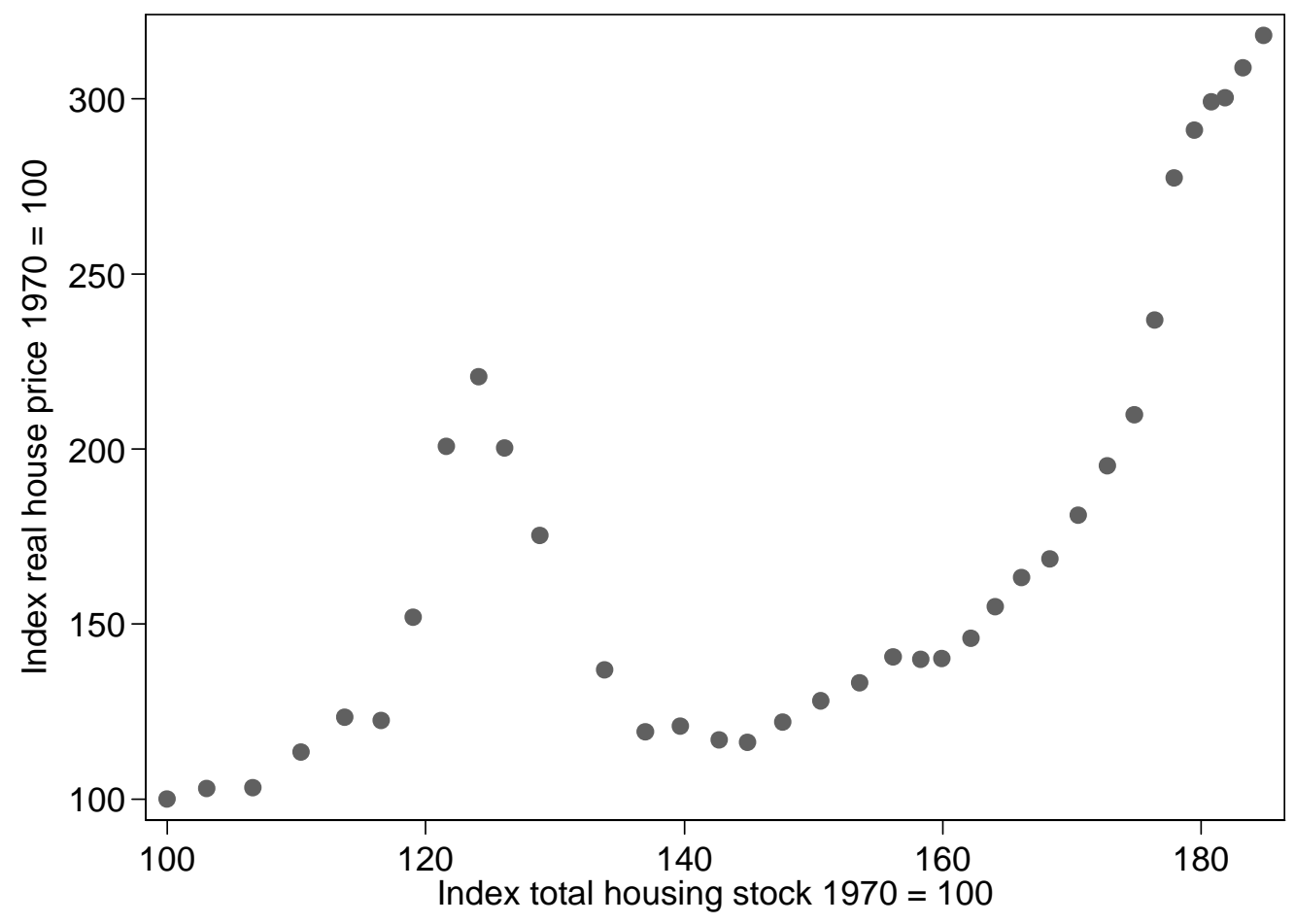


Figure 3: The volume of residential investment and real house price changes

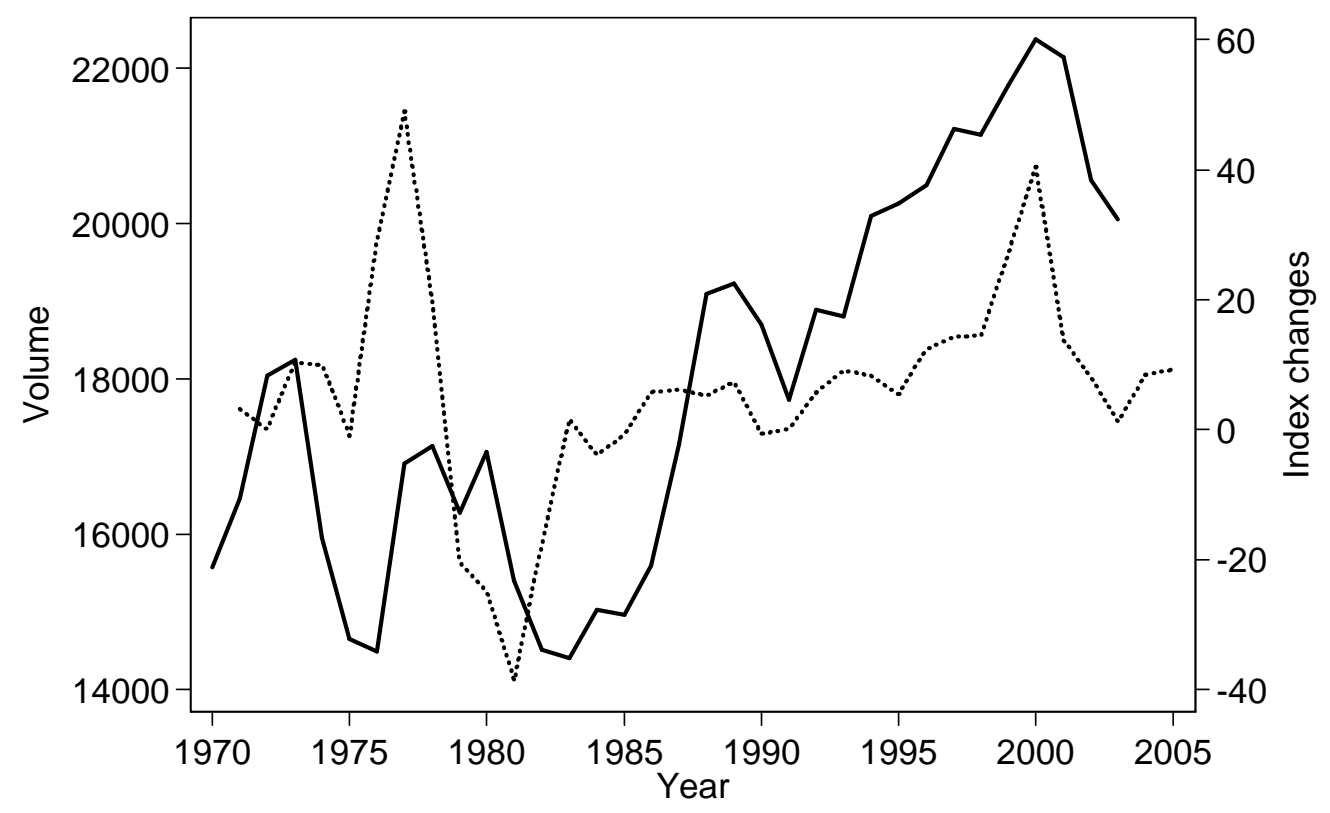

Volume of residential investment

Figure 4: New construction in units and real house price changes

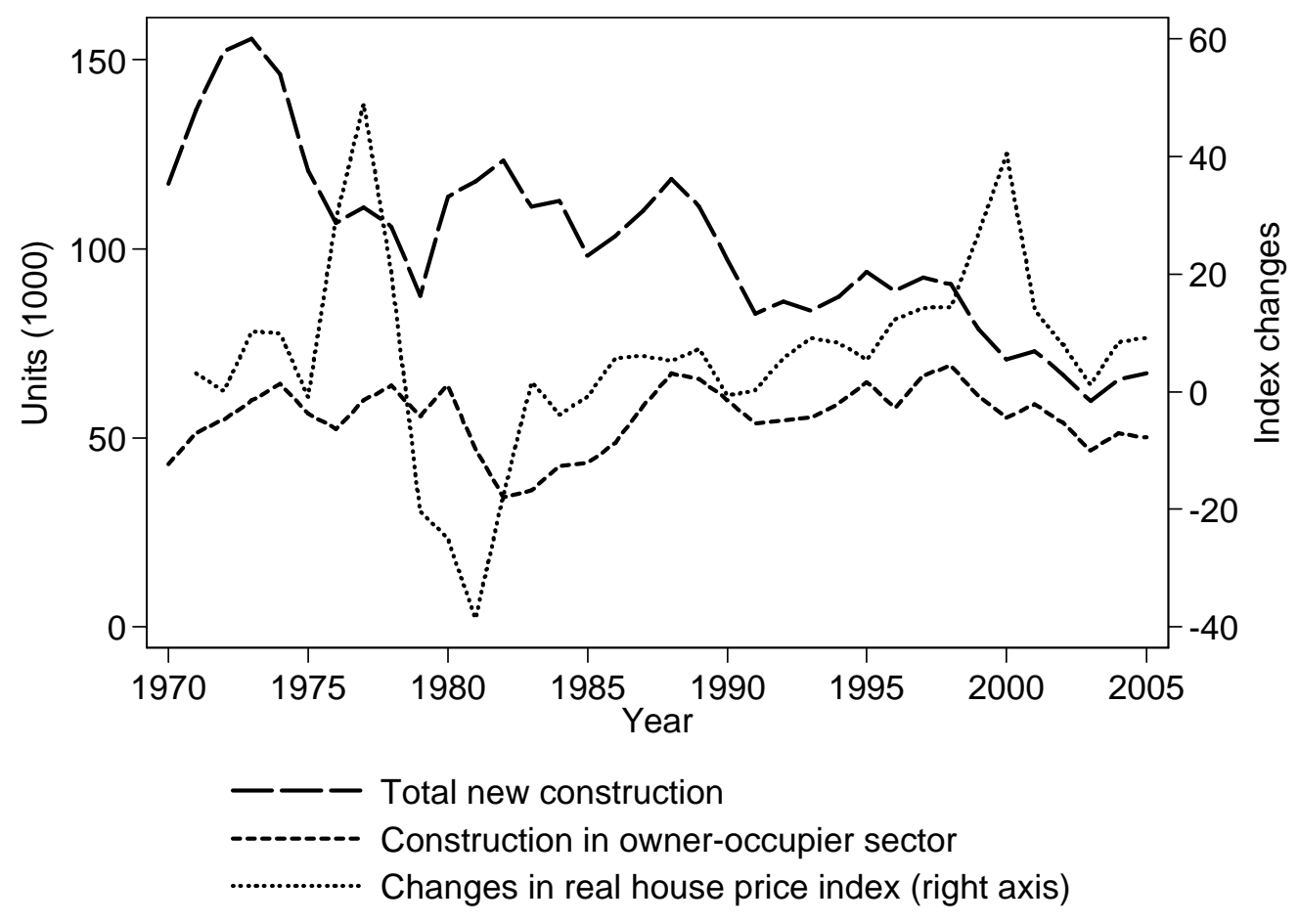


Figure 5: Indices of building quality

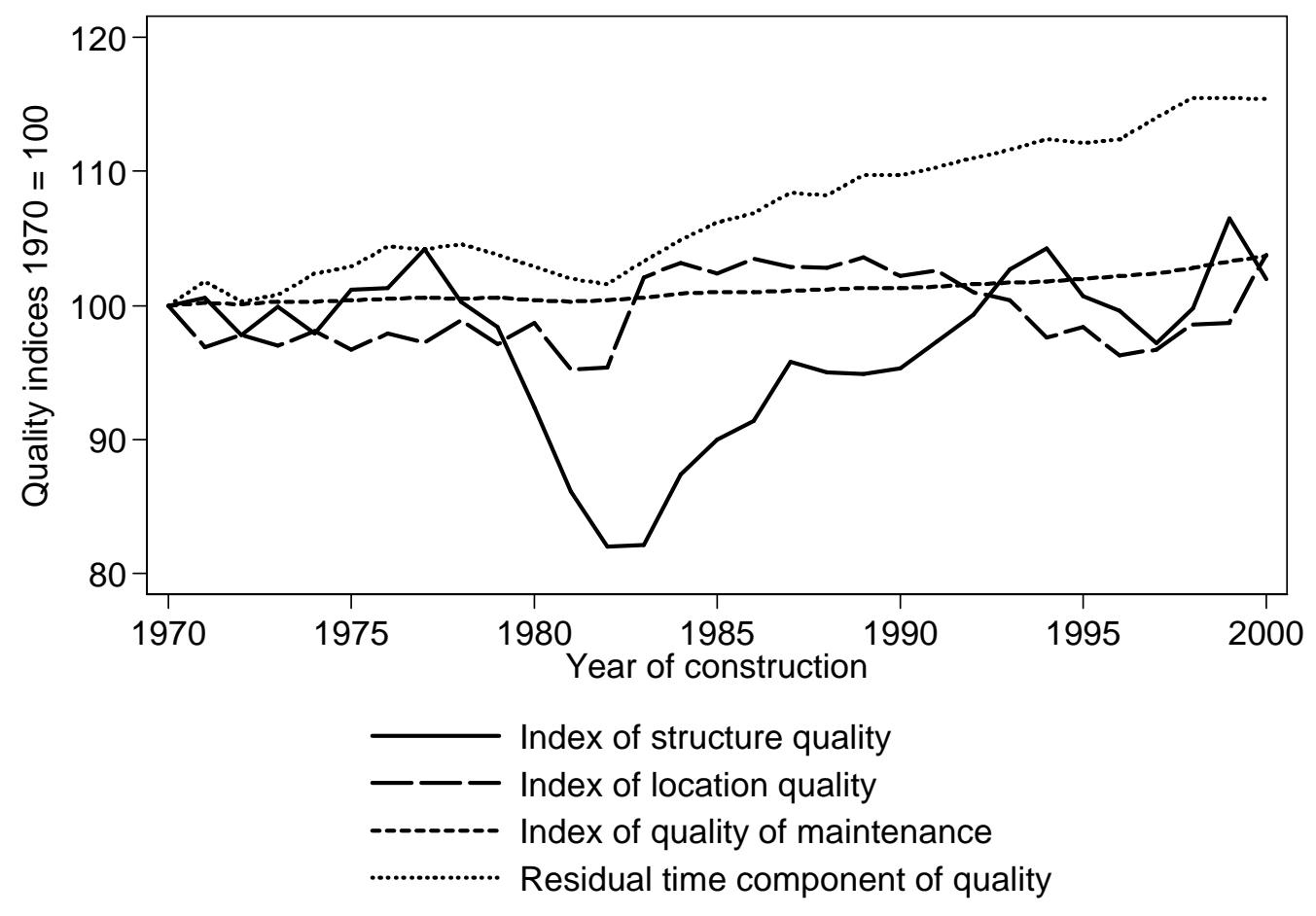

Figure 6: A scatter plot of location quality and the total housing stock

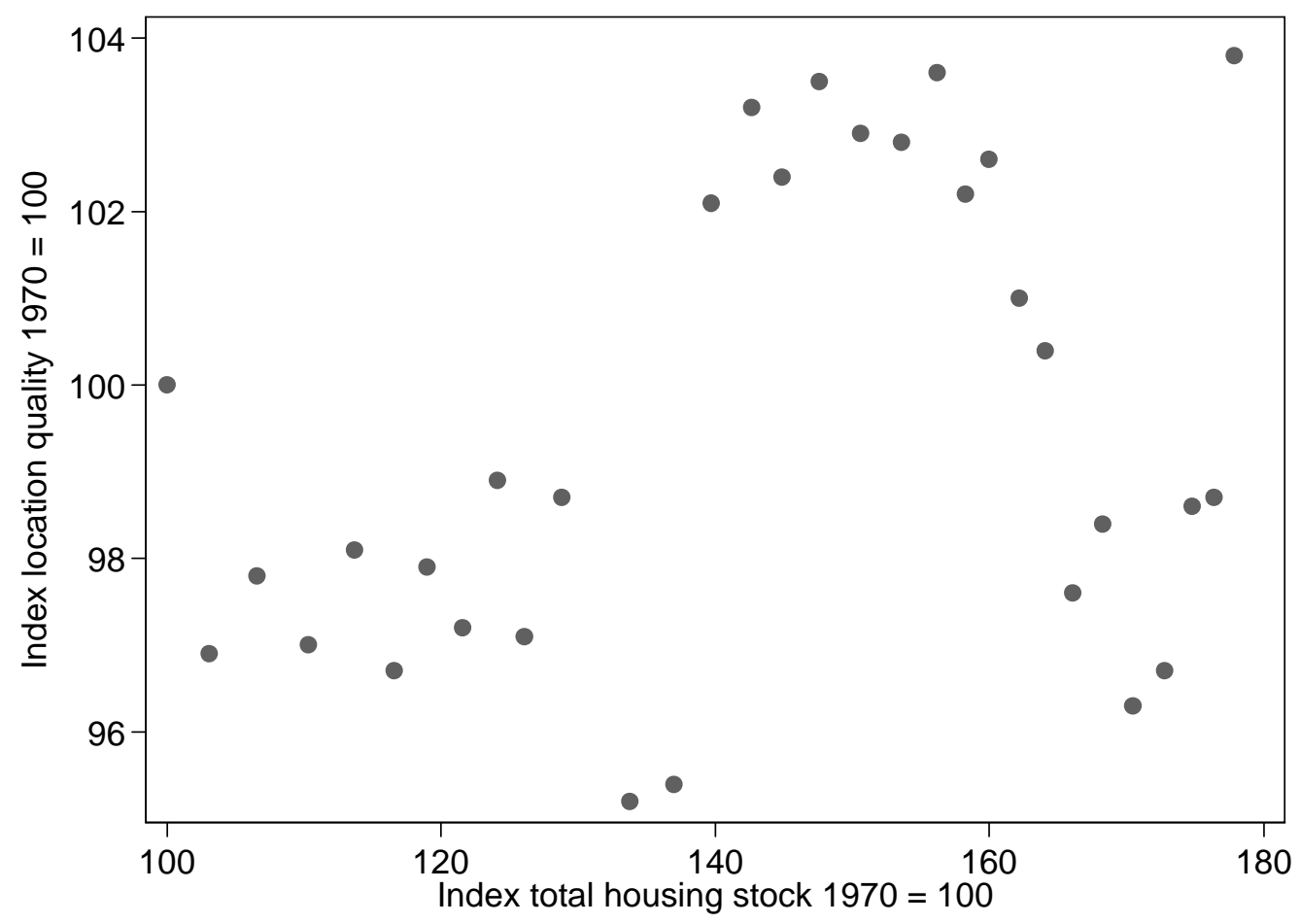

